\title{
25 jaar TMO
}

In mei 1982 verscheen voor het eerst het Bulletin Medisch Onderwijs (BMO). In hun redactioneel spreken de initiatiefnemers, Caspar Bleys, Herman van Rossum en Maarten Verwijnen, de verwachting uit dat het Bulletin een "(...) uitwisselingsplaats zal worden voor ideeën, plannen en pogingen om het medisch onderwijs te verbeteren." In de jaren daarop volgend groeide het animo voor het bulletin gestaag. De uitgave werd vanaf 1993 geprofessionaliseerd en BMO kon vier keer per jaar verschijnen. In 2000 werd na een lange discussie de naam 'bulletin' vervangen door 'tijdschrift'. Daarmee was het huidige Tijdschrift voor Medisch Onderwijs geboren (TMO). Tegelijk met de naamsverandering werden ook de productie en verspreiding van het tijdschrift verbeterd dankzij de medewerking van uitgeverij Bohn Stafleu van Loghum. Zo onderging het een metamorfose van een bundeling van A4-tjes bijeengebonden door twee nietjes tot een volwaardig tijdschrift. De initiatiefnemers uit 1982 hebben met hun eerste bulletin aan de wieg gestaan van een tijdschrift dat als één van de meest zichtbare 'producten' van de $\mathrm{Ne}$ derlandse Vereniging van Medisch Onderwijs (NVMO) een erkend forum is geworden voor medisch onderwijs in Nederland en Vlaanderen.

Dit jaar zullen wij op verschillende manieren aandacht schenken aan het 25-jarig bestaan van het TMO. De voorkant is inmiddels getooid met een lauwerkrans, in de loop van het jaar zullen onderwerpen van 'toen' bekeken worden met de bril van 'nu' en het laatste nummer van deze $25^{\mathrm{e}}$ jaargang zal een speciaal lustrumnummer worden. Voorts zullen we dit jaar samen met het Nederlands Tijdschrift voor Geneeskunde een nieuwe rubriek 'pro en contra discussie over medisch onderwijs' starten.

Degenen die hun BMO's en later TMO's hebben bewaard, zullen gemakkelijk de metamorfose van het tijdschrift vaststellen. Wellicht is die verandering symbolisch voor wat er in die 25 jaren in het medisch onderwijs veranderd is. Was aanvankelijk medisch onderwijs iets waar je als docent vanzelfsprekend geschikt voor was, en bepaalden in de praktijk logistiek en administratieve randvoorwaarden de programmering, anno 2006 is dat een situatie die gelukkig niet meer herkend wordt. Nadenken over hoe een effectieve leeromgeving kan worden gecreëerd, een centrale aansturing van het onderwijs, het belang van professioneel gedrag en de aandacht voor de professionalisering van docenten, zijn enkele voorbeelden van voorwaarden die we nu als vanzelfsprekend beschouwen. En waren het vroeger vooral onderwijskundigen en niet-medici die het NVMOcongres bezochten en over medisch onderwijs publiceerden, tegenwoordig zijn medici zelf minstens zo actief. Die verandering is natuurlijk niet alleen maar in het TMO merkbaar. Ook internationaal gezien is de belangstelling voor medisch onderwijs en de betrokkenheid van de medische beroepsgroep sterk toegenomen. Grote, internationale tijdschriften met een sterk biomedische traditie publiceren inmiddels met regelmaat over onderwijs en de specialistenopleiding. Een goed voorbeeld 
daarvan is een recent artikel van Papadakis et al. Nadat de auteurs al eerder de resultaten van een pilot in een onderwijskundig tijdschrift hadden gepubliceerd, ${ }^{1}$ beschrijven zij nu in de New England Journal of Medicine van 22 december jl. de resultaten van een grote case-controlstudie onder huisartsen en medisch specialisten, afgestudeerd aan drie gerenommeerde Amerikaanse universiteiten, tegen wie in de periode 1990-2003 medisch tuchtrechterlijke maatregelen zijn genomen. ${ }^{2}$ Van die maatregelen bleek $74 \%$ te berusten op onprofessioneel gedrag (bijvoorbeeld alcohol- en drugsgebruik dat de patiëntenzorg in gevaar bracht, crimineel gedrag, verwaarlozing en veronachtzaming van patiënten, seksuele intimidatie, et cetera), $6 \%$ op medische fouten en $20 \%$ op gedrag dat niet gerelateerd was aan het uitoefenen van de medische professie. Van deze veroordeelde artsen zijn de dossiers die bijgehouden waren door de universiteit waar de betrokkenen hadden gestudeerd, onderzocht. Veroordeelde artsen hadden als student statistisch significant vaker onprofessioneel gedrag vertoond. Onder de verschillende soorten van onprofessioneel gedrag was dat het meest duidelijk voor het gebrek aan verantwoordelijkheidsgevoel (ook buiten de studie), onvoldoende reflectie op het onprofessionele handelen zonder initiatief tot het nemen van maatregelen om het eigen gedrag te verbeteren, en gedrag gevoed door angst en onzekerheid. Voorts was er een associatie met slechte studieresultaten in de eerste twee jaren van de studie.
Deze studie is om meerdere redenen interessant. Enigszins generaliserend is onprofessioneel gedrag als huisarts of specialist kennelijk voorspelbaar. Dat betekent dat we niet genoeg aandacht kunnen schenken aan onderwijs in professionaliteit tijdens de opleiding. Voorts moeten we hoge eisen blijven stellen aan de vorderingen van studenten op het gebied van hun professionele attitude om op tijd in te kunnen grijpen als deze onvoldoende zijn. Daarnaast kun je je afvragen of deze bevindingen niet een handvat voor selectie van medisch studenten geven. Een combinatie van onvoldoende studievorderingen en onvoldoende professionaliteit zou wellicht vaker tot een judicium abeundi moeten leiden. Bij een studie waar zoveel belangstelling voor is, zoals geneeskunde, ligt het voor de hand om te proberen diegenen op te leiden die uiteindelijk het beroep op adequate wijze zullen uitoefenen. Het onderzoek van Papadakis dwingt ons daarom het huidige systeem van selectie en toetsing van aankomende artsen nog eens kritisch te evalueren.

\section{Jan Borleffs}

\section{Literatuur}

1. Papadakis MA, Hodgson CS, Teherani A, Kohatsu ND. Unprofessional behavior in medical school is associated with subsequent disciplinary action by a state medical board. Acad Med 2004;79:244-9.

2. Papadakis MA, Teherani A, Banach MA, Knettler TR, Rattner SL, Stern DT, et al. Disciplinary action by medical boards and prior behavior in medical school. New Engl J Med 2005;353:2673-82. 